\title{
The effects of $\mathrm{Ca}^{2+}$ and $\mathrm{Cd}^{2+}$ on the secondary and tertiary structure of bovine testis calmodulin
}

\author{
A circular-dichroism study
}

\author{
Stephen R. MARTIN* and Peter M. BAYLEY \\ Division of Physical Biochemistry, National Institute for Medical Research, Mill Hill, London NW7 1AA, U.K.
}

\begin{abstract}
Near-u.v. and far-u.v. c.d. spectra of bovine testis calmodulin and its tryptic fragments $\left(\mathrm{TR}_{1} \mathrm{C}, \mathrm{N}\right.$-terminal half, residues 1-77, and $\mathrm{TR}_{2} \mathrm{C}, C$-terminal half, residues 78-148) were recorded in metal-ion-free buffer and in the presence of saturating concentrations of $\mathrm{Ca}^{2+}$ or $\mathrm{Cd}^{2+}$ under a range of different solvent conditions. The results show the following: (1) if there is any interaction between the $N$-terminal and $C$-terminal halves of calmodulin, it has no apparent effect on the secondary or tertiary structure of either half; (2) the conformational changes induced by $\mathrm{Ca}^{2+}$ or $\mathrm{Cd}^{2+}$ are substantially greater in $\mathrm{TR}_{2} \mathrm{C}$ than they are in $\mathrm{TR}_{1} \mathrm{C}$; (3) the presence of $\mathrm{Ca}^{2+}$ or $\mathrm{Cd}^{2+}$ confers considerable stability with respect to urea-induced denaturation, both for the whole molecule and for either of the tryptic fragments; (4) a thermally induced transition occurs in whole calmodulin at temperatures substantially below the temperature of major thermal unfolding, both in the presence and in the absence of added metal ion; (5) the effects of $\mathrm{Cd}^{2+}$ are identical with those of $\mathrm{Ca}^{2+}$ under all conditions studied.
\end{abstract}

\section{INTRODUCTION}

The heat- and acid-stable protein calmodulin mediates the effects of the intracellular messenger $\mathrm{Ca}^{2+}$. Calmodulin usually interacts with its receptor protein only after $\mathbf{C a}^{2+}$ is bound (Klee, 1980; Klee et al., 1980). Although it is clear that the binding of $\mathrm{Ca}^{2+}$ causes large conformational changes in the protein (Klee, 1980), there is still considerable uncertainty with regard to the sequence of binding to the four $\mathrm{Ca}^{2+}$-binding sites and also the absolute values of the association constants. However, extensive n.m.r. studies (Forsén et al., 1980, 1983; Andersson et al., 1982) suggest that the $\mathrm{Ca}^{2+}$-binding sites can be grouped into two sites with high affinity and two with low affinity.

Limited tryptic cleavage of calmodulin in the presence of saturating amounts of $\mathrm{Ca}^{2+}$ results in cleavage at lysine-77, thus giving rise to two peptides of equal size (Walsh et al., 1977; Drabikowski et al., 1977, 1982). N.m.r. studies (Andersson et al., 1983) have shown that $\mathrm{TR}_{1} \mathrm{C}(\mathrm{N}$-terminal half, residues $1-77)$ contains the two weak $\mathrm{Ca}^{2+}$-binding sites whereas $\mathrm{TR}_{2} \mathrm{C}(C$-terminal half, residues 78-148) contains the two strong $\mathrm{Ca}^{2+}$-binding sites. This assignment has been confirmed by stopped-flow studies (Martin et al., 1985).

Recent reports have indicated that $\mathrm{Cd}^{2+}$ is a convenient and reliable probe in the study of the $\mathrm{Ca}^{2+}$-binding sites in several different $\mathrm{Ca}^{2+}$-binding proteins (for review see Vogel et al., 1983a).

There have been a number of reports on the effects of $\mathrm{Ca}^{2+}$ on the c.d. of calmodulin, but they show considerable variability. Here we aim to resolve some of the conflicting data in the literature. We report a comparison of the effects of $\mathrm{Ca}^{2+}$ and $\mathrm{Cd}^{2+}$ on the secondary and tertiary structure of bovine testis calmodulin and its tryptic fragments, as well as the effect of these metal ions on the stability of calmodulin towards heat- and urea-induced denaturation.

\section{METHODS}

Bovine testis calmodulin and its tryptic fragments were prepared as described elsewhere (Andersson et al., 1983; Vogel et al., 1983b). The purity of calmodulin and the fragments was checked by both SDS/polyacrylamide-gel and agarose-gel electrophoresis. A small contamination (less than $5 \%$ ) of each fragment with the other cannot be excluded, because of partly overlapping bands on both SDS/polyacrylamide-gel and agarose-gel electrophoresis (Thulin et al., 1984). $\mathrm{Ca}^{2+}$-free proteins were prepared by passage through a Chelex-100 column; the residual metal ion was determined by atomic absorption spectroscopy (approx. $0.05 \mathrm{~mol}$ of $\mathrm{Ca}^{2+} / \mathrm{mol}$ of protein). Protein concentrations were determined by amino acid analysis. All other chemicals used were of analytical grade and were obtained from local suppliers. The standard buffer used in this work was 20 mM-Pipes/KOH, pH 7.0.

C.d. spectra were recorded from 310 to $255 \mathrm{~nm}$ or from 260 to $200 \mathrm{~nm}$ with a Jasco J41-C spectropolarimeter equipped with a J-DPY data processor, with sensitivity of 0.5 milidegrees $/ \mathrm{cm}$ and with an instrumental time constant of $4 \mathrm{~s}$. Fused silica cuvettes of path length 0.1, 1 or $10 \mathrm{~mm}$ were used as required. Reported spectra were recorded at $18^{\circ} \mathrm{C}$ and represent the averages of at least four scans. The spectra are presented in terms of molar ellipticity, based on mean residue weights of 112.7 (whole calmodulin), $111.2\left(\mathrm{TR}_{1} \mathrm{C}\right)$ or $114.3\left(\mathrm{TR}_{2} \mathrm{C}\right)$. Near-u.v. c.d. spectra were recorded at a protein concentration in the range $3-5 \mathrm{mg} / \mathrm{ml}$, and far-u.v. c.d. spectra were recorded with a protein concentration in the range $0.1-0.15 \mathrm{mg} / \mathrm{ml}$ ( $1 \mathrm{~mm}$ cuvette) or $1-1.5 \mathrm{mg} / \mathrm{ml}(0.1 \mathrm{~mm}$ cuvette). The sample temperature was monitored directly in the cuvette with a Comark model 3002 electronic thermometer.

The general procedure for studying the effect of added metal ions was as follows. The spectrum of the metal-ion-free protein was recorded after the addition of

* To whom correspondence should be addressed.

Vol. 238 


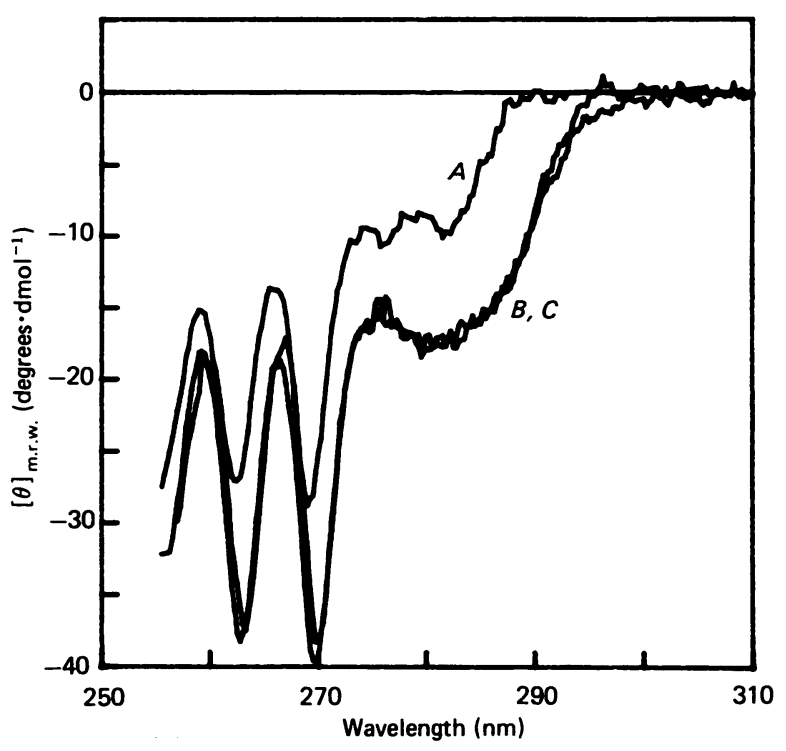

Fig. 1. Effects of $\mathrm{Ca}^{2+}$ and $\mathrm{Cd}^{2+}$ on the near-u.v. c.d. spectra of calmodulin

Spectra were recorded at $18^{\circ} \mathrm{C}$ in standard buffer (20 mm-Pipes/KOH, pH 7.0). Spectrum $A$, whole calmodulin in standard buffer; spectrum $B$, plus excess $\mathrm{Ca}^{2+}$; spectrum $C$, plus excess $\mathrm{Cd}^{2+}$.

EDTA to a final concentration of $0.25 \mathrm{mM}(0.10 \mathrm{~mm}$ for far-u.v. c.d. spectra), and the spectrum of the metalion-saturated form was obtained after the addition of metal ion to a final concentration of $1.5 \mathrm{mM}$ for $\mathrm{Ca}^{2+}$ or $\mathrm{Cd}^{2+}$ and 5-25 $\mathrm{mm}$ for $\mathrm{Mg}^{2+}$.

\section{RESULTS}

Near-u.v. c.d. spectra

Fig. 1 shows the near-u.v. c.d. spectra of bovine testis calmodulin in metal-ion-free buffer and with excess $\mathrm{Ca}^{2+}$ (and $\mathrm{Cd}^{2+}$ ). Identical results are obtained in buffers containing $150 \mathrm{~mm}-\mathrm{KCl}$. The signal above $275 \mathrm{~nm}$ arises from the two tyrosine residues (positions 99 and 138, $C$-terminal half); the prominent bands at 262 and $268 \mathrm{~nm}$ are attributed to phenylalanine residues. The conformational change induced by binding of metal ions clearly perturbs the environment of both tyrosine and phenylalanine residues.

Figs. 2(a) and 2(b) show the effect of $\mathrm{Ca}^{2+}$ on the near-u.v. c.d. spectra of the tryptic fragments. As expected, $\mathrm{TR}_{1} \mathrm{C}$ shows contributions only from phenylalanine residues, whereas $T_{2} C$ shows a spectrum qualitatively similar to that of calmodulin but with a relatively larger component from tyrosine residues. Addition of excess $\mathrm{Ca}^{2+}$ leads to major intensity changes from $T R_{2} C$ but only to small changes for $T R_{1} C$. The addition of $\mathrm{Cd}^{2+}$ to the fragments gives effects indistinguishable from those shown for $\mathrm{Ca}^{2+}$.

We have compared the spectrum of calmodulin with the spectrum generated by the summation for the fragment spectra (with appropriate weighting). Both in the presence and in the absence of $\mathrm{Ca}^{2+}$ (or $\mathrm{Cd}^{2+}$ ) the summation is indistinguishable from the spectrum of the whole molecule (results not shown), thereby indicating that tryptic cleavage does not produce tertiary-structure changes that significantly affect the environment of the aromatic amino acid residues.

\section{Far-u.v. c.d. spectra}

Fig. 3 shows the far-u.v. c.d. spectra of bovine testis calmodulin; this Figure includes three spectra for the $\mathrm{Ca}^{2+}$-free form and two for the $\mathrm{Ca}^{2+}$-saturated form, to give an indication of reproducibility. The addition of $\mathrm{Ca}^{2+}$ produces a significant increase (approx. $21 \%$ ) in the intensity of the c.d. signal. Although $\mathrm{Cd}^{2+}$ behaves identically, this is generally not the case for other metal ions, and we confirm that the effects induced by saturating concentrations of $\mathbf{M g}^{2+}$ are substantially smaller (cf. Wolff et al., 1977; Walsh et al., 1979; Drabikowski et al., 1982).
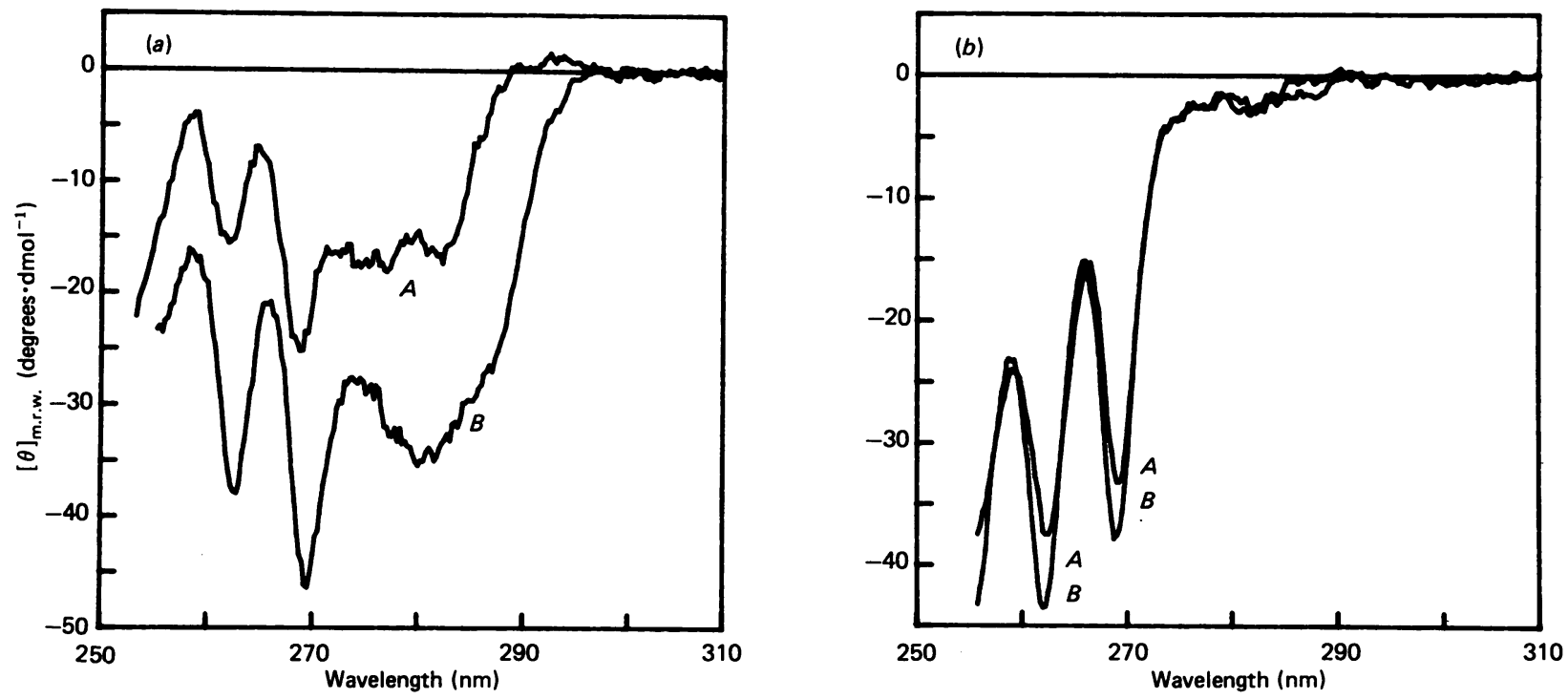

Fig. 2. Effects of $\mathrm{Ca}^{2+}$ on the near-u.v. c.d. spectra of tryptic fragments of calmodulin

Conditions were as indicated in Fig. 1 legend. (a) $\mathrm{TR}_{2} \mathrm{C}$ in standard buffer (spectrum $A$ ) and plus excess $\mathrm{Ca}^{2+}($ spectrum $B$ ).

(b) $\mathrm{TR}_{1} \mathrm{C}$ in standard buffer (spectrum $A$ ) and plus excess $\mathrm{Ca}^{2+}$ (spectrum $B$ ). 


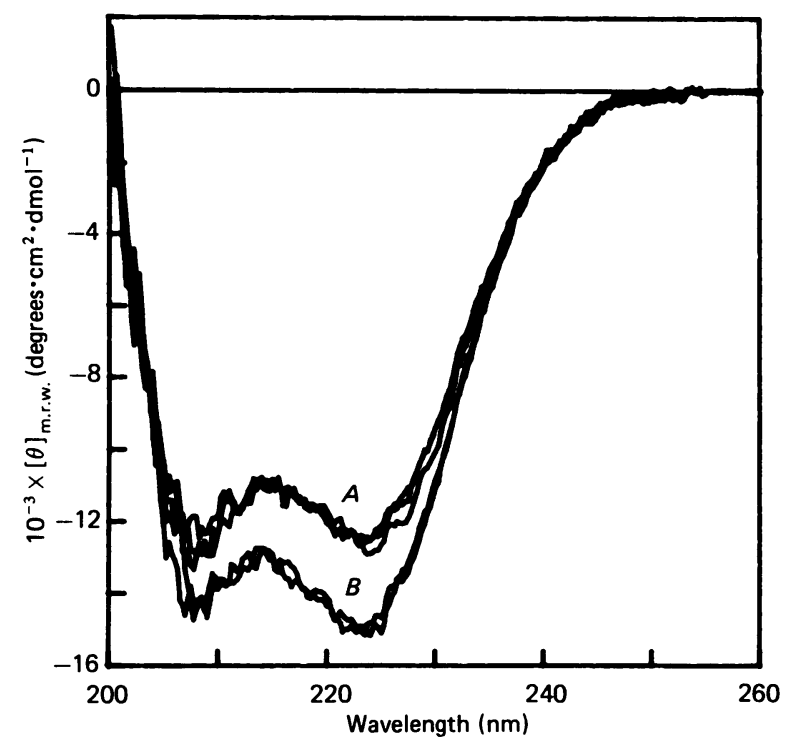

Fig. 3. Effects of $\mathrm{Ca}^{2+}$ and $\mathrm{Cd}^{2+}$ on the far-u.v. c.d. spectra of calmodulin

Spectra were recorded at $18^{\circ} \mathrm{C}$ in standard buffer (20 mm-Pipes/KOH, pH 7.0). Spectrum $A$, whole calmodulin in standard buffer; spectrum $B$, plus excess $\mathrm{Ca}^{2+}$.

Figs. 4(a) and 4(b) show the far-u.v. c.d. spectra of the tryptic fragments. In the absence of added metal ion, the spectrum of $T_{R_{1}} \mathrm{C}$ is more intense than that of the whole molecule, whereas that of $\mathrm{TR}_{2} \mathrm{C}$ is correspondingly less intense (c.f. Drabikowski et al., 1982). However, in the presence of added $\mathrm{Ca}^{2+}$ the two fragments show spectra with almost equal intensity, which is very close to the spectrum of the whole molecule. The effect of $\mathrm{Cd}^{2+}$ is again identical, and the summation of the fragment spectra is identical with the spectrum of the intact molecules under all conditions.

\section{Effects of urea}

Figs. $5(a)-5(d)$ show c.d. intensity $(222 \mathrm{~nm})$ as a function of urea concentration for calmodulin (and its tryptic fragments) in metal-ion-free buffer and in the presence of saturating concentrations of $\mathrm{Ca}^{2+}\left(\right.$ or $\left.\mathrm{Cd}^{2+}\right)$. In agreement with previous results (Walsh et al., 1979), the stability of calmodulin to urea denaturation is increased by the presence of $\mathrm{Ca}^{2+}$; very similar effects are elicited by $\mathrm{Cd}^{2+}$. In addition, the presence of either metal ion substantially enhances the stability of each fragment to urea denaturation. In the absence of $\mathrm{Ca}^{2+}$ both fragments are slightly more sensitive to urea than is calmodulin, with $T R_{1} C$ being more stable than $T R_{2} C$.

\section{Effects of temperature}

Fig. 6 shows the effect of temperature on the c.d. spectrum of calmodulin over the range $10-45^{\circ} \mathrm{C}$ both in the presence and in the absence of added $\mathrm{Ca}^{2+}$. This temperature range is significantly below the major thermal unfolding transition of calmodulin.

\section{DISCUSSION}

Values reported for the intensity of the far-u.v. c.d. spectrum of calmodulin show considerable variability, both in the absolute intensity and in the magnitude of the change caused by $\mathrm{Ca}^{2+}$ binding (Table 1). Effects of $\mathrm{pH}$ and buffer ions do not appear to be a major contributing factor; spectra recorded in a buffer consisting of $50 \mathrm{~mm}-\mathrm{Tris} / \mathrm{HCl}$ at $\mathrm{pH} 8.0$ are identical with those shown here. Although effects of salt have been reported by Crouch \& Klee (1980) and by Hennessey \& Johnson (1982), we find no effects of added $\mathrm{KCl}$ at concentrations up to $150 \mathrm{~mm}$ in either far-u.v. or near-u.v. c.d. spectra. By contrast, temperature is clearly a possible contributing factor, and this is discussed further below. Experimental consistency is probably a major contributing factor (cf. Hennessey \& Johnson, 1982). Probable sources of error
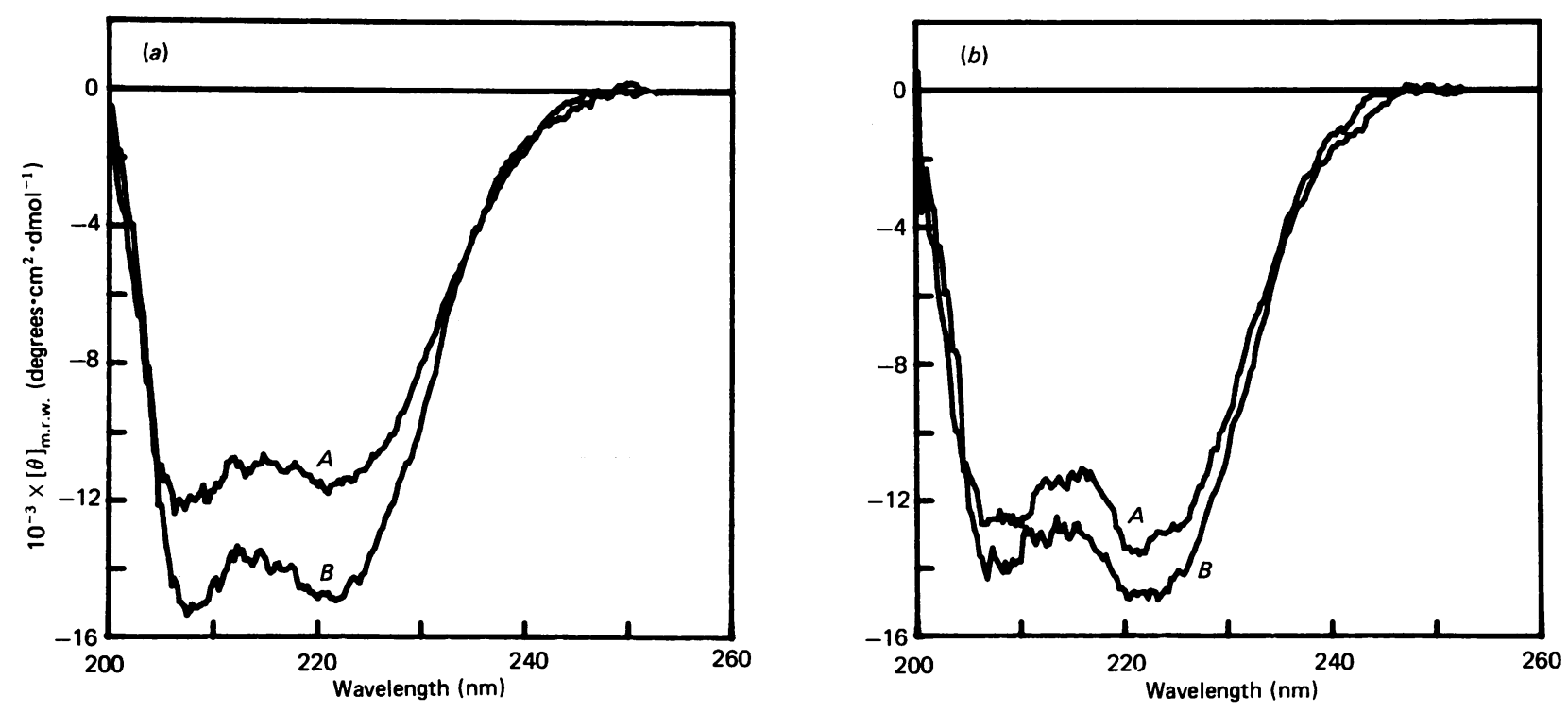

Fig. 4. Effects of $\mathrm{Ca}^{2+}$ on the far-u.v. c.d. spectra of tryptic fragments of calmodulin

Conditions were as indicated in Fig. 3 legend. (a) $\mathrm{TR}_{2} \mathrm{C}$ in standard buffer (spectrum $A$ ) and plus excess $\mathrm{Ca}^{2+}$ (spectrum $B$ ).

(b) $\mathrm{TR}_{1} \mathrm{C}$ in standard buffer (spectrum $A$ ) and plus excess $\mathrm{Ca}^{2+}$ (spectrum $B$ ). 

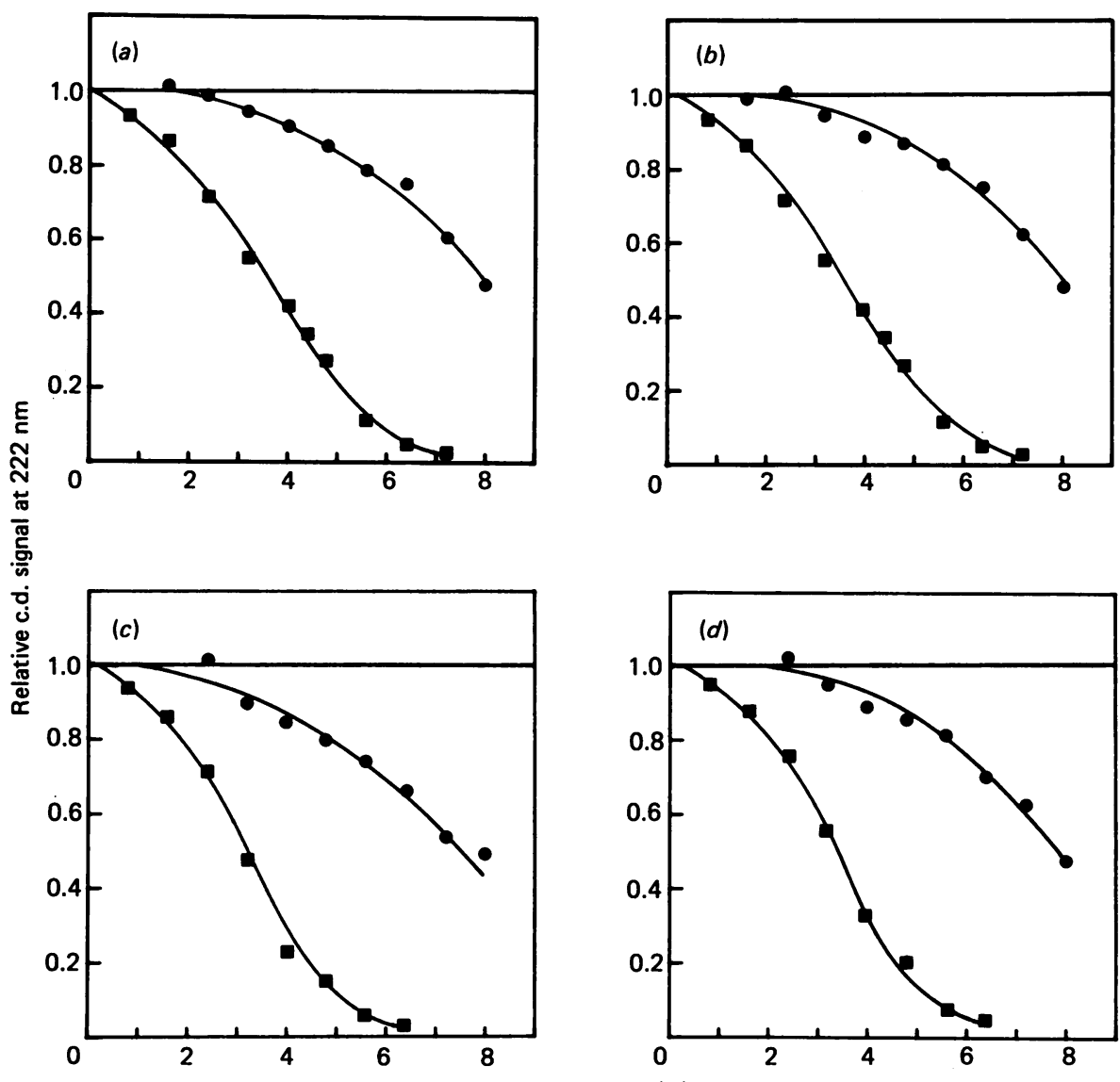

Concn. of urea $(\mathrm{M})$

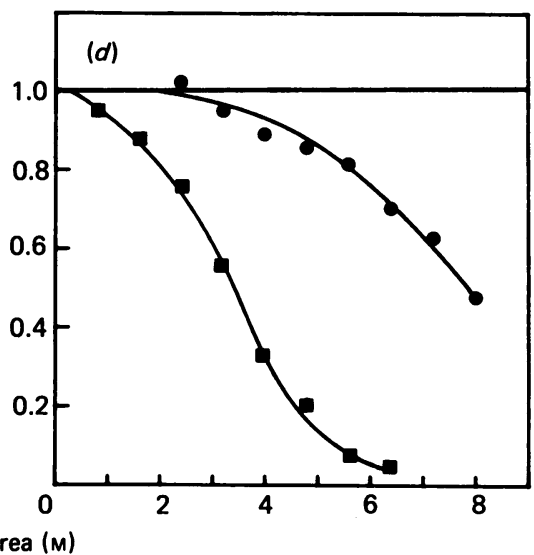

Fig. 5. Effect of urea on the relative intensity of the c.d. signal at $222 \mathrm{~nm}$ for calmodulin and its tryptic fragments

Spectra were recorded at $18^{\circ} \mathrm{C}$ in standard buffer. (a) Whole calmodulin without $(\square)$ and with (O) added $\mathrm{Ca}^{2+}$. (b) Whole calmodulin without $(\square)$ and with $(O)$ added $\mathrm{Cd}^{2+} .(c) \mathrm{TR}_{1} \mathrm{C}$ without $(\square)$ and with $(O)$ added $\mathrm{Ca}^{2+}$. (d) $\mathrm{TR}_{2} \mathrm{C}$ without $(\square)$ and with (O) added $\mathrm{Ca}^{2+}$.

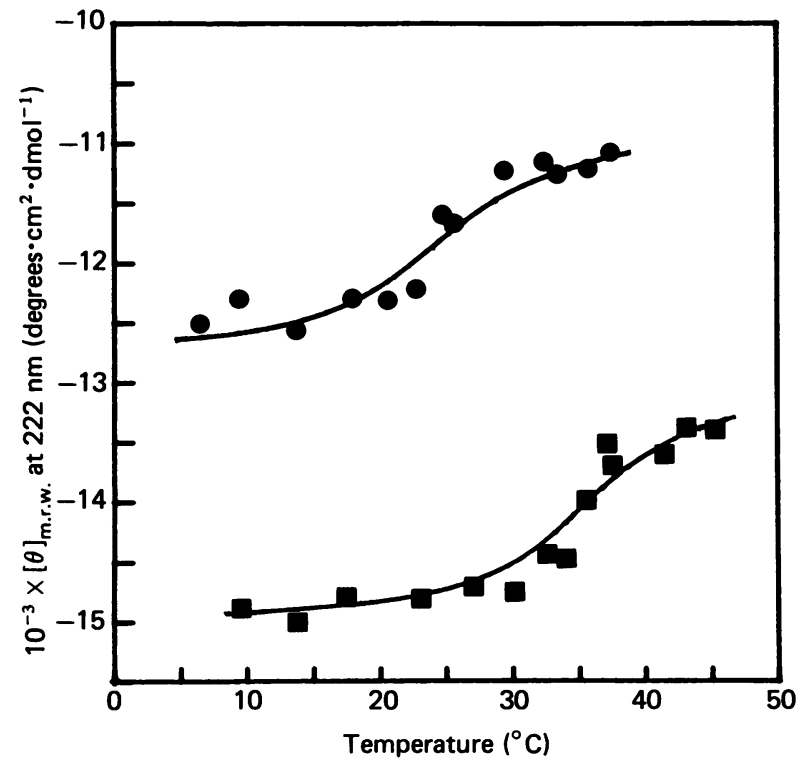

Fig. 6. Effect of temperature on the intensity of the c.d. signal at $222 \mathrm{~nm}$ for whole calmodulin

Spectra were recorded in standard buffer. Whole calmodulin without $(O)$ and with $(\square)$ added $\mathrm{Ca}^{2+}$. are instrument calibration, determination of sample concentration and incorrect baseline correction procedures. We have attempted to minimize these problems by running all samples under carefully controlled conditions; use of careful instrument calibration [(+)-camphor-10sulphonic acid] and use of amino acid analysis to determine concentration.

The far-u.v. c.d. spectra of the tryptic fragments of calmodulin are very similar to those of the whole molecule, except for minor variations in intensity. In metal-ion-free buffer the values of $[\theta]_{222}$ (means \pm S.D.) are $-12300( \pm 300),-13300( \pm 400)$ and -11400 $( \pm 300)$ degrees $\cdot \mathrm{cm}^{2} \cdot \mathrm{dmol}^{-1}$ for calmodulin, $\mathrm{TR}_{1} \mathrm{C}$ and $\mathrm{TR}_{2} \mathrm{C}$ respectively. These values increase by 21,29 and $9 \%$ respectively in the presence of saturating concentrations of $\mathrm{Ca}^{2+}\left(\right.$ or $\left.\mathrm{Cd}^{2+}\right)$. As a consequence of the relative magnitude of these increases, the spectra of calmodulin and its fragments are very similar in the presence of added metal ion (compare Figs. 3 and 4).

The near-u.v. c.d. spectra reported here are similar to those reported by Kilhoffer et al. (1981), but differ substantially from those reported by other workers (see Table 2). The intensities that we find are rather higher than those generally found, the increase in intensity induced by the addition of $\mathrm{Ca}^{2+}$ (or $\mathrm{Cd}^{2+}$ ) is large (cf. Walsh et al., 1979) and we see no effect of added $\mathrm{KCl}$ 
Table 1. Far-u.v. c.d. intensities of calmodulin

\begin{tabular}{|c|c|c|c|c|}
\hline \multicolumn{2}{|c|}{ Without added $\mathrm{Ca}^{2+}$} & \multicolumn{2}{|c|}{ With added $\mathrm{Ca}^{2+}$} & \multirow[b]{2}{*}{ Reference } \\
\hline $\begin{array}{c}{[\theta]_{222}} \\
\left(\text { degrees } \cdot \mathrm{cm}^{2} \cdot \mathrm{dmol}^{-1}\right)\end{array}$ & $\begin{array}{c}\text { Helix } \\
\text { content } \\
(\%)\end{array}$ & $\begin{array}{c}{[\theta]_{222}} \\
\left(\text { degrees } \cdot \mathrm{cm}^{2} \cdot \mathrm{dmol}^{-1}\right)\end{array}$ & $\begin{array}{c}\text { Helix } \\
\text { content } \\
(\%)\end{array}$ & \\
\hline $\begin{array}{l}-11200 \\
-15400 \\
-14700 \\
-12000 \\
-12900 \\
-11500 \\
-13300 \\
-12200\end{array}$ & $\begin{array}{c}28 \\
\frac{25}{40} \\
-\overline{30-35} \\
31 \\
38-40\end{array}$ & $\begin{array}{l}-15100 \\
-19750 \\
-18200 \\
-14700 \\
-15000 \\
-15300 \\
-14800\end{array}$ & $\begin{array}{c}42 \\
54 \\
49 \\
- \\
35-43 \\
37 \\
45-48\end{array}$ & $\begin{array}{l}\text { Wolff et al. (1977) } \\
\text { Drabikowski et al. (1982) } \\
\text { Dedman et al. (1977) } \\
\text { Walsh } \text { et al. }(1979) \\
\text { Richman \& Klee (1978) } \\
\text { Klee (1977) } \\
\text { Siegel \& Haug (1983) } \\
\text { Present work* }\end{array}$ \\
\hline
\end{tabular}

* Structure predictions quoted here were performed by the method of Provencher \& Glockner (1981).

Table 2. Near-u.v. c.d. intensities of calmodulin

\begin{tabular}{|c|c|c|c|c|}
\hline $\begin{array}{c}{[\theta]_{262}} \\
\left(\text { degrees } \cdot \mathrm{cm}^{2} \cdot \mathrm{dmol}^{-1}\right)\end{array}$ & $\begin{array}{c}{[\theta]_{268}} \\
\left(\text { degrees } \cdot \mathrm{cm}^{2} \cdot \mathrm{dmol}^{-1}\right)\end{array}$ & $\begin{array}{c}{[\theta]_{280}} \\
\left(\text { degrees } \cdot \mathrm{cm}^{2} \cdot \mathrm{dmol}^{-1}\right)\end{array}$ & $\begin{array}{l}\text { Concn. } \\
\text { of } \mathrm{KCl} \\
(\mathrm{mM})\end{array}$ & Reference \\
\hline \multicolumn{5}{|l|}{ Without added $\mathrm{Ca}^{2+}$ : } \\
\hline-29.6 & -30.1 & -9.2 & 150 & Kilhoffer et al. (1981) \\
\hline-14.9 & -14.1 & -5.2 & 0 & Crouch \& Klee (1980) \\
\hline-21.9 & -23.0 & -6.1 & 100 & Crouch \& Klee (1980) \\
\hline-20.7 & -19.6 & -4.2 & 150 & Walsh et al. (1979) \\
\hline-5.83 & -4.5 & +1.8 & 0 & Wolff et al. (1977)* \\
\hline-28.0 & -30.0 & -9.8 & 0 & Present work \\
\hline \multicolumn{5}{|l|}{ With added $\mathrm{Ca}^{2+}$ : } \\
\hline-38.9 & -38.7 & -17.5 & 150 & Kilhoffer et al. (1981) \\
\hline-28.9 & -31.7 & -14.9 & 100 & Crouch \& Klee (1980) \\
\hline-24.9 & -20.3 & -6.7 & 150 & Walsh et al. (1979) \\
\hline-16.4 & -15.8 & -7.2 & 0 & Wolff et al. (1977) \\
\hline-38.0 & -40.0 & -17.5 & 0 & Present work \\
\hline
\end{tabular}

* The spectrum recorded by these workers in the absence of $\mathrm{Ca}^{2+}$ actually shows a strong positive maximum at about $273 \mathrm{~nm}$ with $[\theta]_{273}$ approx. 5.0 degrees $\cdot \mathrm{cm}^{2} \cdot \mathrm{dmol}^{-1}$.

(150 mM) (cf. Crouch \& Klee, 1980). Since the fundamental band shape is consistent, the variations probably arise from the experimental problems outlined above.

The results presented here show that, if there is any interaction between the two halves of calmodulin, it has no effect on the environment of the aromatic amino acid residues. Although this is in agreement with studies using other physical techniques, it must be emphasized that we have no information about the relative contribution of each residue to the total intensity of the c.d. spectrum. However, the high intensity per residue $\left\{[\theta]_{262}^{\text {Phe equals }}\right.$ $-830\left(+\mathrm{Ca}^{2+}\right)$ and $-720\left(-\mathrm{Ca}^{2+}\right)$ degrees $\cdot \mathrm{cm}^{2} \cdot \mathrm{dmol}^{-1}$ for $\mathrm{TR}_{1} \mathrm{C}$ and equals $-660\left(+\mathrm{Ca}^{2+}\right)$ and $-270\left(-\mathrm{Ca}^{2+}\right)$ degrees $\cdot \mathrm{cm}^{2} \cdot \mathrm{dmol}^{-1}$ for $\left.\mathrm{TR}_{2} \mathrm{C}\right\}$ indicates that the c.d. signal probably consists of contributions from each residue (Strickland, 1974). The small effect of $\mathrm{Ca}^{2+}$ on the near-u.v. c.d. spectrum of $T_{R_{1}} C$ is rather surprising in view of the similar distribution of phenylalanine residues in the two fragments, but may be related to the observation that the intensity per residue of phenylalanine in the metal-ion-free form of $T_{1} C$ is already very high.

Walsh et al. (1979) reported that metal-ion-free calmodulin was completely unfolded by $6 \mathrm{M}$-urea whereas the $\mathrm{Ca}^{2+}$-saturated form retained $60 \%$ of its structure at this urea concentration. The results presented here confirm this result for $\mathrm{Ca}^{2+}$ and show that added $\mathrm{Cd}^{2+}$ produces an identical effect. Furthermore, the stabilizing effect of $\mathrm{Ca}^{2+}$ and $\mathrm{Cd}^{2+}$ also exists for both of the tryptic fragments.

Temperature affects the conformational properties of calmodulin and its tryptic fragments at temperatures substantially below those of major thermal unfolding. [ $T_{\frac{1}{2}}$ values for the major transition are 55,49 and $45^{\circ} \mathrm{C}$ in the absence of $\mathrm{Ca}^{2+}$ for whole calmodulin, $T R_{1} \mathrm{C}$ and $T R_{2} \mathrm{C}$ respectively, and $>90^{\circ} \mathrm{C}$ for each species in the presence of $\mathrm{Ca}^{2+}$ (Brzeska et al., 1983).] Such low-temperature effects have been noted elsewhere. Brzeska et al. (1983) demonstrated (for metal-ion-free calmodulin) that a plot of $\mathrm{d}[\theta]_{222} / \mathrm{d} T$ against $T$, which showed a maximum at $55^{\circ} \mathrm{C}$ (major transition), showed an unexplained shoulder at $30^{\circ} \mathrm{C}$. Drabikowski et al. (1982) showed that an increase in temperature from 12 to $27^{\circ} \mathrm{C}$ results in an $8 \%$ decrease in ellipticity at $222 \mathrm{~nm}$ (metal-ion-free calmodulin), and that changes in temperature affect the amplitude of the $\mathrm{Ca}^{2+}$-induced changes in $[\theta]_{222}$, as confirmed here (see Fig. 6). Both Kilhoffer et al. (1981) 
and Gangola \& Pant (1983) have found discontinuities (interpreted as conformational changes) in plots of fluorescence intensity at temperatures below $40^{\circ} \mathrm{C}$; however, they disagree about the influence of $\mathrm{Ca}^{2+}$ on the change. Our results show that transitions in this temperature range do, in fact, occur in the presence and in the absence of added $\mathrm{Ca}^{2+}$.

Under all conditions used in this work we can find no evidence that tryptic cleavage of calmodulin leads to changes in the secondary or tertiary structure of the two halves (cf. Martin et al., 1985), supporting the idea that calmodulin is constructed from two largely independent domains. The effects of $\mathrm{Cd}^{2+}$ are identical with those of $\mathrm{Ca}^{2+}$, thus confirming the view that $\mathrm{Cd}^{2+}$ behaves as a close analogue of $\mathrm{Ca}^{2+}$ (Vogel et al., 1983a). Other metal ions generally induce changes different from those produced by $\mathrm{Ca}^{2+}$; thus both $\mathrm{Mg}^{2+}$ and $\mathrm{Mn}^{2+}$ induce only small increases, and $\mathrm{Al}^{3+}$ causes a decrease in intensity in the far-u.v. c.d. spectrum (Siegel \& Haug, 1983).

$\mathrm{Ca}^{2+}\left(\right.$ and $\left.\mathrm{Cd}^{2+}\right)$ clearly induce substantial conformational changes in calmodulin and its tryptic fragments. The magnitude of the change is greater for $\mathrm{TR}_{2} \mathrm{C}$ than for $\mathrm{TR}_{1} \mathrm{C}$, and this may correlate with the location of the strong $\mathrm{Ca}^{2+} / \mathrm{Cd}^{2+}$-binding sites in $\mathrm{TR}_{2} \mathrm{C}$. The conformational change greatly increases the stability of calmodulin (and its tryptic fragments) to both urea- and temperatureinduced denaturation. Finally, we have shown that calmodulin (in both the metal-ion-free and the metalion-saturated form) undergoes a small conformational transition at temperatures substantially below the main thermally induced transition.

We are very grateful to Professor S. Forsén (University of Lund, Lund, Sweden) for providing calmodulin and its tryptic fragments, and for helpful discussions.

\section{REFERENCES}

Andersson, A., Drakenberg, T., Forsén, S. \& Thulin, E. (1982) Eur. J. Biochem. 126, 501-505

Received 6 February 1986/1 April 1986; accepted 2 May 1986
Andersson, A., Forsén, S., Thulin, E. \& Vogel, H. J. (1983) Biochemistry 22, 2309-2313

Brzeska, H., Venyaminov, S. V., Grabarek, Z. \& Drabikowski, W. (1983) FEBS Lett. 153, 169-173

Crouch, T. H. \& Klee, C. B. (1980) Biochemistry 19, 3692-3698

Dedman, J. R., Potter, J. D., Jackson, R. L., Johnson, J. D. \& Means, A. R. (1977) J. Biol. Chem. 252, 8415-8422

Drabikowski, W., Kuznicki, J. \& Grabarek, Z. (1977) Biochim. Biophys. Acta 485, 124-133

Drabikowski, W., Brzeska, H. \& Venyaminov, S. Y. (1982) J. Biol. Chem. 257, 11584-11590

Forsén, S. Thulin, E., Drakenberg, T., Krebs, J. \& Seamon, K. (1980) FEBS Lett. 117, 189-194

Forsén, S., Andersson, A., Drakenberg, T., Teleman, O. \& Vogel, H. J. (1983) in Calcium-Binding Proteins (de Bernard, B., ed.), pp. 121-131, Elsevier, Amsterdam

Gangola, P. \& Pant, H. C. (1983) Biochem. Biophys. Res. Commun. 111, 301-305

Hennessey, J. P. \& Johnson, W. C. (1982) Anal. Biochem. 125, $177-182$

Kilhoffer, M.-C., Demaille, J. G. \& Gerard, D. (1981) Biochemistry 20, 4407-4414

Klee, C. B. (1977) Biochemistry 16, 1017-1024

Klee, C. B. (1980) Calcium Cell Funct. 1, 59-77

Klee, C. B., Crouch, T. H. \& Richman, P. G. (1980) Annu. Rev. Biochem. 49, 489-515

Martin, S. R., Andersson-Teleman, A., Bayley, P. M., Drakenberg, T. \& Forsén, S. (1985) Eur. J. Biochem. 151, 543-550

Provencher, S. W. \& Glockner, J. (1981) Biochemistry 20, 33-37

Richman, P. G. \& Klee, C. B. (1978) Biochemistry 17, 928-935

Siegel, N. \& Haug, A. (1983) Biochim. Biophys. Acta 744, $36-45$

Strickland, E. H. (1974) CRC Crit. Rev. Biochem. 2, 113-175

Thulin, E., Andersson, A., Drakenberg, T., Forsén, S. \& Vogel, H. J. (1984) Biochemistry 23, 1862-1870

Vogel, H. J., Drakenberg, T. \& Forsén, S. (1983a) in NMR of Newly Accessible Nuclei (Laszlo, P., ed.), pp. 157-199, Academic Press, New York

Vogel, H. J., Lindahl, L. \& Thulin, E. (1983b) FEBS Lett. 157, 241-246

Walsh, M., Stevens, F. C., Kuznicki, J. \& Drabikowski, W. (1977) J. Biol. Chem. 252, 7440-7443

Walsh, M., Stevens, F. C., Oikawa, K. \& Kay, C. M. (1979) Can. J. Biochem. 57, 267-278

Wolff, D. J., Poirier, P. G., Broström, C. O. \& Broström, C. A. (1977) J. Biol. Chem. 252, 4108-4117 